\title{
八ニカム構造の面外圧潰特性
}

\section{Out-of-plane compressive behaivior for Honeycomb structure}

\author{
正 牛島 邦晴 (東理大), $\bigcirc$ 吉田 比呂志 (東理大), \\ 米田裕一 (東理大), 正陳 玳珩 (東理大)
}

Kuniharu USHIJIMA, Hiroshi YOSHIDA, Hirohito YONEDA, Dai-heng CHEN

Tokyo University of Science, 1-3 Kagurazaka, Shinjuku-ku, Tokyo, Japan

Key Words: Buckling, Impact-Strength, FEM, Honeycomb Structure, Deformation Behavior

\section{1 緒言}

本研究では、図1のように正六角形で構成された八二力 么構造が面外方向から衝撃負荷を受ける問題に対し、有限 要素法による数值解析を行い、八二カム構造や衝撃速度の 違いによる圧潰特性への影響について系統的に検討する。

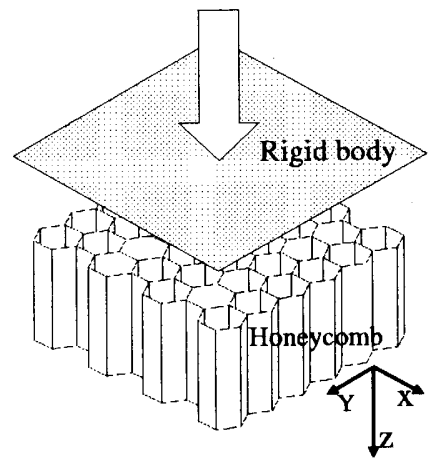

Fig.1 ハニカム構造体

\section{2 研究概要}

本研究では、有限要素法解析ソフトMarc（静解析）/Dy-

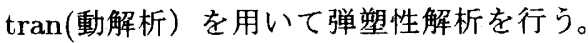

解析に用いるハニカムモデルは以下の 2 つに大別する。

1. 複数のハニカムセルを有する全体モデル

2、八ニカムセルの一部分を切り出した対称モデル (図 2 中の点線で囲まれた B の部分)

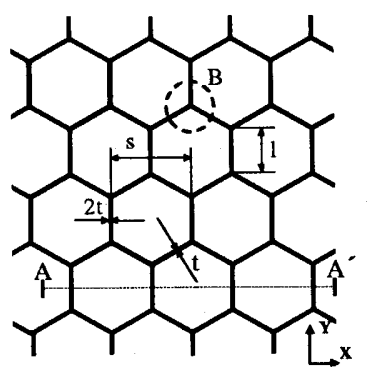

Fig.2 解析モデル

ハニカムモデルのセルサイズ $\mathrm{s}$ は $9.5 \mathrm{~mm}$ とし、セルの 高さ h は $15 \mathrm{~mm}$ 、セル壁一辺の長さ1は $5.48 \mathrm{~mm}$ 、簿厚 $\mathrm{t}$ は $0.1 \mathrm{~mm}$ とし、接着面䈃厚は一般的な製造法を考え 2 倍の 2 $\mathrm{t}$ となっている。材料はアルミニウム材で、降伏点を過ぎた 後の歪と応力の関倸が

$$
\sigma=\sigma_{Y}+E_{h}\left(\epsilon-\frac{\sigma_{Y}}{E}\right)
$$

となる二直線硬化則で近似できるものとし、塑性硬化係数 $E_{h} / E=0.01$ として解析を行った。各材料物性值を表 1 に 示す。全体モデル・対称モデルともに、八ニカムセルの一端 を固定し、他端に剛体板を衝突させ、5 10 $\mathrm{mm}$ まで圧潰し たときのハニカムにかかる荷重と剛体の変位の関係と変形 モードについて検討する。

Table. 1 材料定数

\begin{tabular}{l|c}
\hline ヤング率 & $E=71[\mathrm{GPa}]$ \\
ポアソン比 & $\rho=0.34$ \\
降伏応力 & $\sigma_{Y}=190[\mathrm{MPa}]$ \\
塑性硬化係数 & $\frac{E_{h}}{E}=0.01$ \\
\hline
\end{tabular}

\section{3 解析結果及び検討}

\section{1 解析モデルの違いによる影響}

静解析（㓮体板による強制変位）によって得られた忘力 一変位線図を図 3 、図 4 に示す。ここでは、八二カ厶が受け る荷重と八ニカ厶の受圧面積の比を忘力と定義する。また、 全体モデルの xz 平面の箔厚 $2 \mathrm{t}$ のセル壁の部分の断面形状 （図 2 中の $\mathrm{A}-\mathrm{A}^{\prime}$ 断面）を変形モードとして図 5 に示す。

\subsection{1 全体モデルの検討}

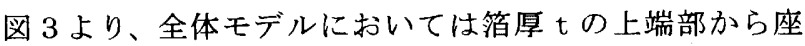
屈が開始し、少し遅れて箔厚 $2 \mathrm{t}$ の上端部の座屈が開始す る。その時最大の忘力值（初期ピーク応力）が生じる。その 後塑性座屈を続けるが、角筒などで見られるような応力の 振幅が見られず、初期ピーク応力の約半分の応力值を一定に 示し続ける。その要因としては、図5の変形モードで見られ るように、同じ箔厚のセル壁でも八二カム周辺部のセル壁 から座屈が始まり、遅れて中央部のセル壁が座屈し始めて、 しわの形成が進行していくといことがあげられる。つまり、 セル壁の位置によって座屈が生じ、進行していくタイミング が異なるために、それぞれのセル壁で生じる応力振幅を互 いに相殺しあい、一定の忘力值を示し続けていると考えら れる。

\subsection{2 対称モデルの検討}

図 4 より、対称モデルにおいては初期ピーク後の応力は 角筒や円筒の面外圧潰と同様に一つのしわが形成されるた びに振幅するため、全体モデルのような一定の忘力值を示 していないという特徴がある。また、変形モードは全体モデ ルと同様にまず䈃厚 $\mathrm{t}$ の部分の座屈が開始し、少し遅れて 箔厚 $2 \mathrm{t}$ の部分の座屈が始まる。ただし、同じ簿厚 $\mathrm{t}$ の部分 は同じタイミングで座屈していくことが見られる。 


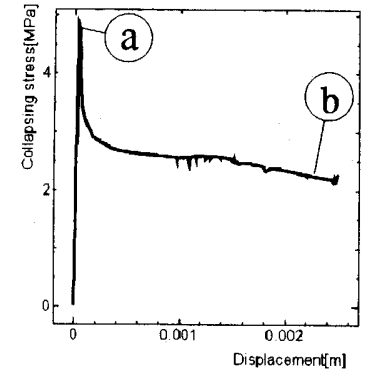

Fig.3 全体モデル

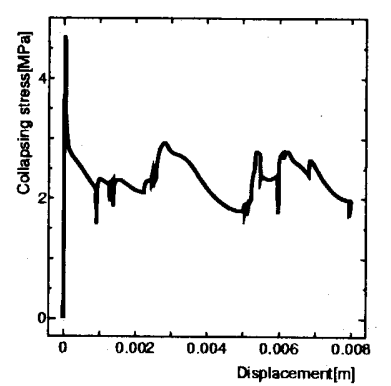

Fig.4 対称モデル

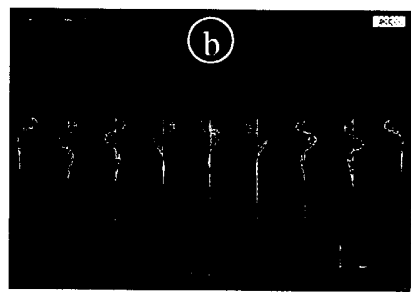

Fig.5 全体モデルの変形モード

次に、表 2 に全体モデルと対称モデルの初期ピーク圭力 值及び平均応力值を示す。これより初期ピーク応力、平均応 力ともにほぼ一致していることがわかる。よって対称モデル は、変形挙動にはおいて全体モデルで見られるような座屈 タイミングの違いや初期ピーク後の忘力振幅は見られない が、初期ピーク応力值及び平均忘力値においては対称モデ ルでの検討の余地はあると考えられる。

Table.2 初期ピーク応力及び平均忘力の比較

\begin{tabular}{|c|c|c|}
\hline & 初期ピーク応力 & 平均応力 \\
\hline 全休モデル & $4.81[\mathrm{Mpa}]$ & $2.41[\mathrm{Mpa}]$ \\
\hline 㳡称モデル & $4.71[\mathrm{Mpa}]$ & $2.34[\mathrm{Mpa}]$ \\
\hline
\end{tabular}

\subsection{3 セル数の異なる全体モデルの検討}

次に図 6 に示すようなセル数 $\mathrm{n}=1,7,19,37$ とするセル数 の異なる全体モデルについて応力一変位線図の挙動を調心゙ る。図 6 より、 $\mathrm{n}=1$ のモデルにおいては角筒や円筒の面外 圧潰と同様に、一つのしわが形成されるたびに态力值が大 きく振幅するという挙動が見られる。しかし $\mathrm{n}=7,19,37$ と セル数が増加するにしたがって応力振幅が収まり、より安定 した挙動になることが分かる。

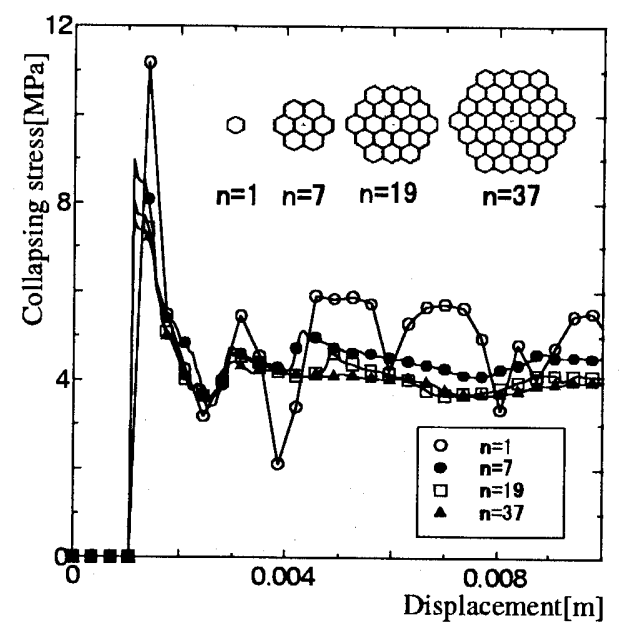

Fig.6 ハニカムセル数に対する応力-変位線図

\section{2 衝突速度による圧潰挙動への影響}

動解析によって㓮体板に速度を与えてハニカム材に衝突 させる解析を行い、これによって得られた忘力一変位線図を 図 7 に示す。ここでの応力は静解析における応力の定義と同 様である。図 7 よ、剛体板に速度を与えてハニカムに衝突 させた場合も、静解析の全体モデルの結果と同様に、初期 ピーク応力が生じた後応力は初期ピーク応力の約半分の值 をほぼ一定に示し続けている。また速度が小さいほど応力 值はより安定している。よって初期ピーク以降に忘力がほと んど振幅しないのはハニカム構造材の面外圧潰の特性であ ると考えられる。

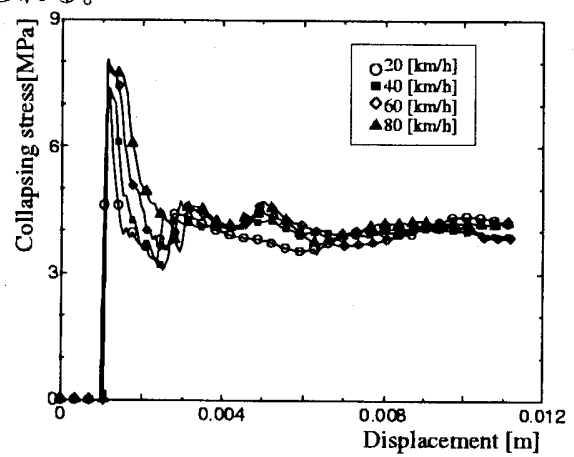

Fig.7 速度変化に対する応力-変位線図

\section{3 衝突速度及び相対厚さの応力値への影響}

次に㓮体衝突速度と八二力ムの厚さ $\mathrm{t}$ の違いによる初期 ピーク応力及び平均応力への影響を図 8 (a)、(b)に示す。こ こで、相対厚さとは八ニカムセル一辺lあたりに対する簿厚 $\mathrm{t}$ の值である。図 8 (a) より、剛体衝突速度が増加するにし たがって、初期ピーク応力もゆるやかに增加している。また 平均応力は㓮体衝突速度に依らず、ほぼ一定值を示している ことがわかる。次に図 8 (b) より、相対厚さの增加に比例し て初期ピーク応力、平均応力ともに增加しているというこ とがわかる。

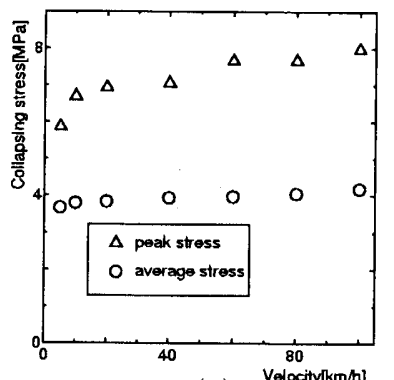

(a)

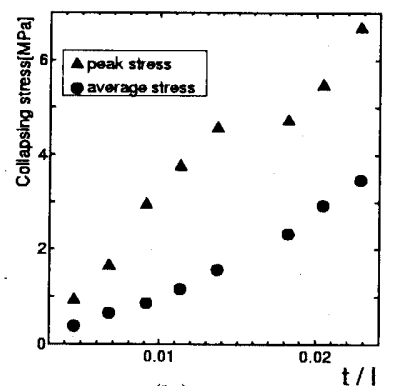

(b)
Fig.8 衝突速度と八ニカムの厚さの応力值への影響

\section{4 結 言}

- 全体モデルは初期ピーク後の応力振幅が見られず安定 したエネルギー吸収を示す。また八二力ムの中央部と 周辺部ではセル壁の座屈するタイミングが異なる。

- 対称モデルは全体モデルとは異なり初期ピーク後に応 力振幅を示す。しかし初期ピーク応力值及び平均応力 值はほぼ全体モデルと一致する。

・セル数が増加するほど応力の振幅が収まる。

- 剛体板に速度を与えても応力の振幅は見られず、速度 が小さいほどより安定したエネルギー吸収を示す。

- 平均応力値は剖体板衝突速度のに依らずほぼ一定の值 を示す。また、相対厚さに比例する。 